\title{
CARBON CREDIT: A STEP TOWARDS GREEN ENVIRONMENT
}

\author{
RAHUL PANDEY \\ Assistant Professor, School of Banking and Finance, Jagran Lakecity University, \\ Bhopal, Madhya Pradesh, India
}

\begin{abstract}
APSTRACT
The climate in these days is radically changing due to the massive amounts of carbon-dioxide being thrown into the atmosphere. The lasting effects can be witnessed with the darkening of the sky in the last few years. The term Global warming is coined to explain the accumulation of carbon dioxide into the air, and the rapid changing of our climate as a result. The burning of fossil fuel, planned and unplanned clearing of forests to make space for the factories and other human structures is one among the several reasons for the rising of carbon dioxide. Government authorities and private Government are being made to apply the methods to reduce the quantity of carbon Dioxide in the atmosphere together with the expanding awareness of damaging levels of Greenhouse Gases.

KEYWORDS: Carbon Credit \& Green Environment
\end{abstract}

Received: Feb 24, 2019; Accepted: Mar 14, 2019; Published: Apr 16, 2019; Paper Id.: IJEEFUSJUN20193

\section{INTRODUCTION}

Green environmentalists aim to promote policies and business that works for the environment in a costeffective manner as in today's scenario global warming is a costly affair. The concentration of carbon dioxide, the most important greenhouse gas, which is majorly produced due to the combustion of fuels has created a global panic attack as it is growing exponentially at an alarming rate. A global carbon market got created, marking this as an opportunity to make a trade within and outside of the regulated area. Controls are imposed under the Kyoto Protocolon the Greenhouse gas emissions as per this system of Carbon trading and then allotted to the countries as per the pre-decided emission limits, which ought to control the Greenhouse emissions released from the commercial units operating under them like various industries. Discussion of basic concepts and importance of the carbon credit is the primary objective of this paper alongside emphasizing the methods administered to save the environment. The business opportunities that are created in the global emission markets in the Indian context are also covered to an extent.

\section{BACKGROUND}

The market for greenhouse gas emission reductions by its Carbon finance Business (CFB) is initiated by The World Bank. Projects that generate emission reductions are leveraged with The CFB throughout private and public investment. World Bank is working under the Kyoto Protocol's Clean Development Mechanism (CDM) and Joint Implementation (JI), to make sure that transition and developing markets get a sizable share of the growing carbon market. The customer countries are exchanging growth dollars, technological know-how, and clean technology for sustainable development for providing high quality carbon emission reductions. 
There are many variables and uncertainties to assess like political and economic instability, government taxation, and limited access to new technologies, sales quotas, local currency fluctuation, and subsidies from developing countries to their local industries. External factors and their result that possess the full range of risks are briefly talked upon in this text, while commonly recognized risks are still not elaborated. With the support of case studies from That the World Bank Carbon Finance Business cases regarding how carbon financing is beneficial in addressing the undertaking, limitations are also supplied in the text.

\section{PROJECT FINANCE IN A MACROECONOMIC CONTEXT}

The local interest rates radically improved or local money depreciated drastically with The evolution of the Brazilian market in the past few years is evident from the previous eight years throughout each and each successive international crisis, specifically: the Asian crisis in 1997, the Russian crisis of 1998, the crisis following the September 11th, events in the united states, along with the Argentinean crisis in 2001.

Governments tend to take a defensive stand in response to the increase in international risk by increasing local interest rates. The perception formed as a result of international investors and financial institutions demanding higher remuneration for their involvement in those "risky markets" that is associated with all developing country markets, or the investors tend to switch their cash investments to places with more favourable "profit over risk ratio". Even I such actions of government do negatively impact their domestic debts, to maintain and attract foreign investments and savings avoid cash outflows from the country, local governments tend to push high their local interest rates.

The abrupt raise in the requirement for hard currency is just another pure effect of financial turbulence both by Nation citizens and businesses, for instance, regional subsidiaries of multinational businesses. The responsible parties of this local authorities, for the upkeep of National reservations, begin to curtail the quantity of hard money made available from the marketplace as a pure supplier of hard currency on the current market and since the accountable party.The local currency devaluation, as in 1999, along with punctual overshoots like in 2001, and in 2002 will be the outcomes of the unbalanced hard money source and demand.Companies found in developing nations and functioning domestically are especially vulnerable.Increased debt-service costs during these periods ${ }^{l}$ lead to adverse situations like Bankruptcy also affects those with ongoing financial liabilities — whether local or foreign-currency-denominated.

\section{AN INSIGHT ON HOW FINANCIAL INSTITUTIONS ANALYSE RISKS}

The risk is also shared by the company's lenders during the lifetime of a loan when such crises occur. The total premium charged by the lender is priced by taking into account any external factor that might negatively affect the borrower's capacity to repay its loanand the likelihood of those events occurring.Country Risk ${ }^{2}$ (also called sovereign and political risk) is coined by combining all these factors.A breakdown of the risks, as adopted by financial institutions are shown in Figure 1

\footnotetext{
${ }^{1}$ Assumes loans with variable rates

${ }^{2}$ The country risk includes every potential constraint for local currency convertibility to hard currency equivalents, cash transferability, asset expropriation, confiscation or nationalization of goods, governmental caps on exports (i.e. increase in local market supply), and a sudden increase in taxation on trade or cash payments abroad.
} 


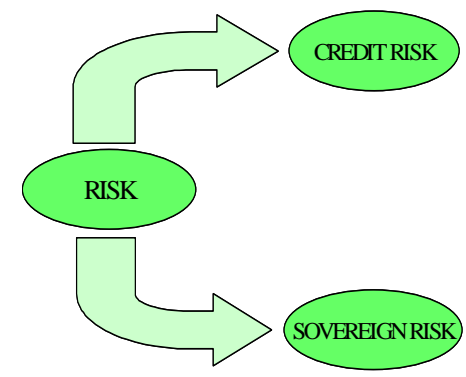

Figure 1: Risks Related to Project Finance in a Developing Country

- Credit base (all companies related to the borrower)

- Legal framework, financial structure, guarantees

- Sector, company (or project) competitive strength

- Confiscation, expropriation, nationalization (CEN)

- Cash convertibility and transferability

- Others such as: banking moratorium, wart, revolution, etc.

Financial institutions set up constraints for loans due to the risks involved, in nations where those risks are somewhat more likely to happen. Since the risk is directly connected to the length of the loan, then this limit is normally defined concerning a maximum cash sum available for loans. Until the nation risks can be mitigated more restrictive constraints are levied into longer-term transactions.Formedium, to long-term obligations (i.e. normally past two to three decades ). It is commonly implemented.

Acquisition of insurance against reinsurance firms have become the most typical method to mitigate Country Risk. Development banks or export credit agencies are just another method. The qualities of the transaction and the risk perception in that particular nation is the determinant of the insurance premium because it's directly related. The premium of the insurance rises drastically, and its accessibility is radically decreased, particularly for longer-term prices, during economic turmoil.

Either because of a tenor limitation for those banks (i.e. that the availability of long-term funding may vanish) or into the price limitation for those borrowers (the project sponsors), a bank's internal necessity for state risk policy can occasionally become a deal-breaker. The all-in cost of the loan increases since always the price for such loan is always passed on to some of the concerned parties.

\section{THE PLANTAR DEAL}

The substitution of coal by charcoal in the pig-iron industry is the essence of the Plantar Project. This is the prototype of the projects formed in Brazil, as one of the projects from which greenhouse gas emission reductions are bought by the Carbon Fund. This is a long time project to generate any cash flows, sometimes up to eight years as Eucalyptus plantations are grown and established in degraded pasture areas, as per the project even under local conditions, it may require seven years to mature and is ready, the timber obtained from the harvest is used to generate charcoal by carbonizing sufficiently, through which pig-iron is produced by subsequently mixing with mineral iron in furnaces. Such long lead time is necessary for the eucalyptus to mature and the process of making Pig-iron is complete. 
Additional Earnings to the project start from the project's next year since the Job's eligibility under the Clean Development Mechanism (CDM) [1] of the Kyoto Protocol and the World Bank agreed to cover the emission reductions (ERs) made during the trees' growth.

There's a natural miss-match in most of the jobs, such as the requirements for upfront investments for construction and the yearly obligations for ERs. This is among the substantial constraints for the CDM to effectively achieve its objectives to promote jobs as the investments are tied to their own delivery, which is generally after the project's conclusion and the annual or periodic verification of the successful greenhouse gas loss. This cannot occur with no carbon credits, because it is precisely the timing of the payment for the emission reductions.

However, this issue was resolved by The expected payment for your ER's from buying emission reduction (in this instance the Prototype Carbon Fund or PCF) is issued to the project sponsor[1], in an ordered manner that could perfectly fit the loan amortization program. The method financing arrangement discussed where the World Bank (as trustee of their $\mathrm{PCF}$ ) paying to get the ERs right into the bank account that's known as the"export "from the lending sector is exemplified in Figure 2.

Further, the substantially complex financial Structure because of federal policies, Central Bank rules, as well as the host's Specific limitations is explained below.It is best to resolve country's risk and considerably change the all-in-cost for the borrower on transactions, by best analyzing each case to determine how best to apply carbon finance as per the PCF experience

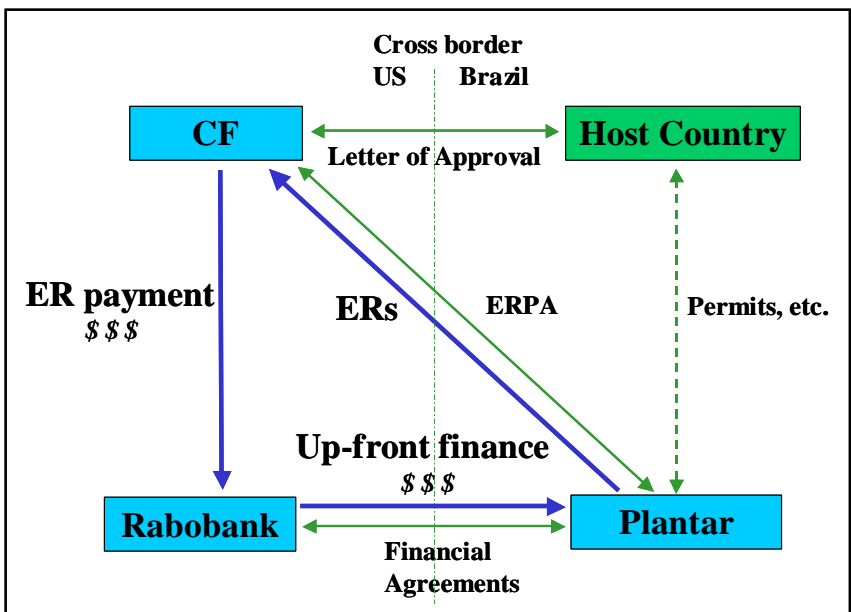

Figure 2: The Loan Structure in the Plantar Deal

General and/or specific risks within this transaction are recorded and identified in the undertaking Finance risk matrix provided in Figure 2, which also describes the limitations Found in advance approval. Mitigation of all the dangers that are identified and Allowing the trades to be concluded with using Carbon Finance will also be pointed out.

\section{Credit Risk (Before ERs)}

Every industry is exposed to external respected each passing day in a new way. Industry demandscontinuous maintenance to face these. The pig iron industry we are discussing in this projectis assumed to be very volatile and risky as per the lenders, and when compared with the coal-based pig iron industries there is no evidence of competitive advantage over sponsor activities. 


\section{ERs as Mitigates}

During the eucalyptus growth, ER's were paid with the annual sequestration of greenhouse gases; now, however, the payments are widely dependent upon industrial activity. That was because the plantation and the maintenance after the plantation were comparatively cheaper. The lender had not faced the risk of delivery regarding the payment. We can now say that such mitigation of credit risk has now reduced with this carbon Credit deal. It can be understood that most of the agroforest industries reduce such credit risk when implemented.

There is a high risk involved in local currency fluctuation when any domestically operating company takes aloan in hard currency. Due to this, the lenders were always sceptical in lending the finance.

Now and agreement has been made in that hard currency so as to mitigate the lender's foreign currency fluctuation rates and local currency depreciation this is the emission reduction purchase agreement (ERPA). This is not only for the sponsors to mitigate the risk but would also help in accessing cheaper International loan for domestic currency. The major companies that represent CDM sponsor for mostly the companies that all into renewable energy, integrated waste management, Energy Efficiency, district heating and agribusinesses. With this agreement when the money is paid back in hard currency, it should definitely capture the interest of investors to accept this.

\section{Credit Risk (Before ERs)}

Another significant risk associated by the exporters is the receipt of revenue when products are exported, and this is maximized when the import is done by developing countries as those are faced by economic risk. Hence the credit risk what existent doesCharcoal importers/ exporter.

The World Bank has always been a risklessbuyer to the lender's eye. Most of the CDM buyers are located mostly in the industrialized countries that are the countries which are committed to reducingtheemission of greenhouse gases under any of the localscheme and operator Hi Re in hard currency. With the World Bank in the picture, search countries have the lowest sovereign risk rate as these are provided by International Financial Institutions. moreover, the companies that are interested in meeting such regulatory targets life emission reduction I mostly the structured organizations which also havepropercredit evaluation, this means the risk of nonpayment is very low, and hence it is suggested the ERPA should focus more security contract and agreements. This main indulge the sellers in offering commodities of high value to lenders as a means of repayment

\section{Country Risk (Before ERPA)}

There is always an involvement of local government when the repayment of the loan in hard currency is involved. This would always hinder the repayment of loans to the lender

\section{ERPA as Litigant}

With the agreement the repayment is directly made into the lenders account associated with the Carbon Finance. This provides natural protection against the race to the exporters, as the buyers belong to the countries with lower sovereign risk rate and the goods are directly provided to lenders to their account. As discussed above most of the buyers are located in structural is industrialized countries and hence this would provide in high mitigation of risk. 


\section{Country Risk}

In regards to the exportation of goods, there is also a risk of confiscation, expropriation of Nationalized right. This is another concern for the sponsors.

\section{CDM as Mitigating}

When it comes to CDM project when a letter of approval is issued by the authorities then there would be no need to worry regarding the government interference in the matter of goods and their export. Hence, almost this risk is eliminated in regards to emission reduction.

As discussed above, there exists several country risks faced by the lender which needs to be mitigated, which can be the purchase of risk insurance by the lender, which would help him hedge himself at the risk markets, and thereby provide the required amount of loans to the plantar project. However, Brazil stands unbendable to this option following the events of September 11th as no country risk was available there.

\section{The Consolidation of the Concept in the Loan to Plantar}

Since the result of Emission reduction project's revenue that is anticipated came into the picture only by year two. Till then the non-convertibility, lack of transfer of currency and loans, the nature of such ER loans, i.e., being intangible, led the lenders to charge the transactions at a rate, coined explicitly as "Country Risk-Free". With the start of this, the loans that were being given became more easily bankable,and the lenders were free of risk insurance. This helped the lenders to support the project more. The lenders started to give loans to the projects and companies, as the perception of risk has changed visibly.

\section{Now Let's Look at an Alternate Approach: The Novagerar Landfill Project.}

Carbon finance plays a significant role as a new financing tool. To understand, let's look at another example. Sponsors of Southern Brazil are aiming at generating electricity from the combustion of Methane Gas generated at a sanitary landfill site, under the Novagerar landfill project. But, unlike in the case of a plantar project, the sponsors faced the problem with investment as they did not have enough upfront capital.

Because of the regulatory problems prevailing in Brazil from 2000 on the energy sector, the sponsors couldn't try to get any bank loans as per the power purchase agreement as collateral to the energy sale, but they were highly reluctant because of the same regulatory issues. Because of the risky investment and viability issues and the project being doubtful, the project struggled for the finance of its investment required.

Yet due to a number of the emission reductions that are generated by the job as well as the World Bank commitment to guarantee all emission reductions are acquired. In some of the cases where the emission reductions that are generated by Job are very high, the common component won't allow full recovery of their investment by the supplier, but also compensate the possible losses which the supplier has run into in the whole period of a project. The agreement signed between the parties at precisely the exact same period that the emission reduction purchase agreement in addition to it requires the emission loss payment to be made directly to the supplier from the UK. The very same sponsor is being approached by lots of the suppliers with different negotiations by different International institutions that may assist in providing the capital requirements as a loan that may be repaired as from the plantar deal. 


\section{CONCLUSIONS}

It is concluded that carbon financing plays an essential role in protecting the suppliers from risk. In some of the projects, the emission reduction is sometimes the sole source of reliable income for the project developers. Hence it is understood that it is very much is essential that the project developers understand the value of emission reduction and make their projects viable in the long run.

\section{REFERENCES}

1. G. Y. Zhuang, "The Way of China's Low-Carbon Economy Development and Analysis of its Potential," International Technical and Economic Research, No. 3, 2005, pp. 79-87.

2. Y. Fu, Y. H. Ma, Y. C. Liu and W. Y. Niu, "Low-Carbon Economic Development Mode," Chinese Population Resources and Environment, No. 3, 2008, pp. 14-19.

3. C. J. Liu and B. M. Feng, "The Revelation of Low-Carbon Economy on the Construction of Wuhan City Circle 'Two Type Society' in China," Chinese Population Resources and Environment, No. 5, 2009, pp. 16-21

4. N. Xiag and F. Xia, "Low-Carbon Economy and Green Development Strategy-The Thought for the First in Hainan to Establish the First National Environmental Protection," China Soft Science, No. 10, 2009, pp. 13-22.

5. Nooriafshar, M. (2015, December). Incorporating case studies into the university courses to heighten awareness about greenhouse gas emissions for a product from seed to supermarket. In Proceedings of the 2015 International Symposium on Business and Social Sciences (TISSS 2015)(pp. 219-224). TISSS.

6. S. Nader, "Paths to a Low-Carbon Economy-The Masdar Example," Energy Procedia, Vol. 1, No. 1, 2009, pp. $3951-3958$. doi:10.1016/j.egypro.2009.02.199

7. B. Jiang, Z. Q. Sun and M. Q. Liu, “China's Energy DeVelopment Strategy under the Low-Carbon Economy,” Energy, In Press, Corrected Proof, Available online 4 February 2010.

8. Ali, A. A. M., Negm, A., Bady, M., \& Gamal, M. (2014). Towards An Integrated Tool To Estimate Carbon Emissions From Life Cycle Assessment Of Building Materials In Egypt. IMPACT: IJRET, 2(3), 81-92.

9. D. Johnston, R. Lowe and M. Bell, "An Exploration of the Technical Feasibility of Achieving CO2 Emission Reductions in Excess of 60\% within the UK Housing Stock by the Year 2050," Energy Policy, Vol. 33, No. 13, 2005, pp. $1643-1659$. doi:10.1016/j.enpol.2004.02.003

10. R. Kawase, Y. Matsuoka and J. Fujino, "Decomposition analysis of CO2 Emission in Long-Term Climate StabiliZation Scenarios,” Energy Policy, Vol. 34, No. 15, 2006, pp. 2113-2122. doi:10.1016/j.enpol.2005.02.005

11. K. Shimada, Y. Tanaka, K. Gomi and Y. Matsuoka, "Developing a Long-Term Local Society Design Methodology towards a Low-Carbon Economy: An application to Shiga Prefecture in Japan,” Energy Policy, Vol. 35, No. 9, 2007, pp. $4688-4703$. doi:10.1016/j.enpol.2007.03.025

12. Pant, M., \& Virdi, A. S. (2018). Sustainability and Scalability of Green Product Purchase Intention. Available at SSRN 3095480.

13. J. Q. Bao, Y. Miao and F. Chen, "Low-Carbon Economy: a New Mode of Economic Development of Human Transformation," China Industrial Economy, No. 4, 2008, pp. 153-160.

14. John, "How Carbon Credits could Drive the Emergence of Renewable Energies," Energy Policy, Vol. 36, No. 10, 2008 , pp. 3633-3639. doi:10.1016/j.enpol.2008.05.033 
15. T. Osborne and C. Kiker, "Carbon Offsets as an Economic Alternative to Large-Scale Logging: A Case Study in Guyana," Ecological Economics, Vol. 52, No. 4, 2005, pp. 481-496. doi:10.1016/j.ecolecon.2004.06.003

16. K. Siriwardena, P. D. C. Wijayatunga, W. J. L. S. Fernando, R. M. Shrestha and R. A. Attalage, "Economy Wide Emission Impacts of Carbon and Energy Tax in Electricity Supply Industry: A Case Study on Sri Lanka," Energy Conversion and Management, Vol. 48, No. 7, 2007, pp. 1975-1982. doi:10.1016/j.enconman.2007.01.030

17. J. Peace and T. Juliani, "The Coming Carbon Market and Its Impact on the American Economy," Policy and Society, Vol. 27, No. 4, 2009, pp. 305-316. doi:10.1016/j.polsoc.2009.01.002

18. Chaurey and T. C. Kandpal, "Carbon Abatement Potential of Solar Home Systems in India and Their Cost Reduction Due to Carbon Finance,” Energy Policy, Vol. 37, No. 1, 2009, pp. 115-125. doi:10.1016/j.enpol.2008.07.038

19. J. I. Lewis, "The Evolving Role of Carbon Finance in Promoting Renewable Energy Development in China," Energy Policy, In Press, Corrected Proof, Available online 6 February 2010.

20. W. F. Ren, "Low-Carbon Economy and Environment of Financial Innovation,” Shanghai Economic Research, No. 3, 2008, pp. 38-42. 